Al-Amwal: Jurnal Ekonomi dan Perbankan Syariah
ISSN: 2303-1573 e-ISSN: 2527-3876
Homepage: https://www.syekhnurjati.ac.id/jurnal/index.php/amwal
email: jurnalalamwal @ syekhnurjati.ac.id

\title{
Asset Growth In Sharia Insurance: Macroeconomic and Internal Factors of Sharia Insurance Companies in Indonesia
}

\author{
Hilmy Baroroh \\ UIN Sunan Kalijaga Yogyakarta \\ email: hilmy.baroroh@uin-suka.ac.id
}

\begin{abstract}
Sharia insurance presents an alternative system in insurance operation with risk sharing in ta'awun (cooperative). Knowledge and insight into reality and trends are used to assess and decide sharia insurance operationalization policies. This study analyzed the growth of Islamic insurance company assets in Indonesia in 2016-2020. The data is sourced from the Sharia Financial Statement Statistics published by OJK and Bank Indonesia Statistics from 2016 - 2020 with multiple linear regression analysis methods. This research aims to find out the influence of internal variables and external variables on the assets growth of sharia insurance in Indonesia. In this study, there are two variables, namely dependent variables and independent variables. Dependent variables are the assets growth of sharia insurance in Indonesia (PERASSET), and independent variables, namely GDP, inflation (INF), contribution (KONB), investment (INVEST), and operating costs (BOPERATE). The results of this study GDP, Inflation, Contributes, and Investment affects Sharia insurance's assets growth. While operating costs do not affect the assets growth of sharia insurance companies.
\end{abstract}

Keywords: Sharia Insurance, Asset Growth, GDP, Inflation, Contribution, Investment, Operating Costs

\begin{abstract}
Abstrak
Asuransi syariah menghadirkan sistem alternatif dalam operasionalisasi asuransi dengan pembagian risiko secara ta'awun (kooperatif). Pengetahuan dan wawasan tentang realitas dan tren digunakan untuk menilai dan memutuskan kebijakan operasionalisasi asuransi syariah. Penelitian ini menganalisis pertumbuhan aset perusahaan asuransi syariah di Indonesia pada tahun 2016-2020. Data bersumber dari Statistik Laporan Keuangan Syariah yang dipublikasi oleh OJK dan Statistik Bank Indonesia dengan
\end{abstract}


periode mulai tahun 2016-2020 dengan metode analisis Regresi Linier Berganda. Fokus penelitian ini untuk mengetahui pengaruh variabel internal dan variabel eksternal terhadap pertumbuhan aset asuransi syariah di Indonesia. Dalam penelitian ini ada dua variabel yaitu variabel dependen dan variabel independent. Variabel dependen yaitu Pertumbuhan Aset asuransi syariah di Indonesia (PERASSET), dan varibel independen yaitu GDP, inflasi (INF), Kontribusi (KONB), Investasi (INVEST), dan Biaya Operasional (BOPERATE). Hasil dari penelitian ini GDP, Inflasi, Kontribusi, dan Investasi berpengaruh terhadap pertumbuhan aset asuransi syariah. Sedangkan biaya operasional tidak berpengaruh terhadap pertumbuhan aset perusahaan asuransi syariah.

Keywords: Asuransi Syariah, Pertumbuhan Aset, GDP, Inflasi, Kontribusi, Investasi, Biaya Operasional

\section{INTRODUCTION}

Non-bank financial institutions become one of the connecting elements of the economy and function as a source of funding that supports economic activities other than banking. In addition, LKNB is also able to protect business risks related to the economy. Like other Non-Bank Financial Institutions, the growth of insurance assets is increasingly advanced and has a hand to build the economy and society by minimizing risk and becoming an intermediator of funds in the form of investments (Rusydiana \& Nugroho, 2017).

Insurance provides a different performance for the household or business sector to prosper them. The superior services offered by insurance companies are related to efforts to minimize the risk of loss of life, property, business, and others. Therefore, insurance companies support both individuals and businesses to mitigate risk in every business and get profits but, of course, with higher risk (Khan Atiquzzafa \& Uzma Noree, 2014).

Conventional insurance companies in recent years have been able to grow rapidly. In the condition of the covid-19 pandemic in 2021 based on the Financial Services Authority (OJK), as of March 2021, in the first quarter of 2021, the general insurance industry posted a premium of Rp19.5 trillion. The acquisition grew 10.7 percent (yearon-year/yoy) from the previous achievement of Rp17.6 trillion (Financial Business 2021).

As this conventional insurance institution continues to grow, on the other hand, the spirit of the sharia economy also develops. This spirit was based on the resilience of Bank Muamalat at the time of the crisis in 1998. This is behind financial institutions to build and pay attention to interest in Islamic finance as well as in banking. One of the Islamic financial institutions is Sharia insurance.

Takaful (Sharia insurance) presents an alternative system in insurance operationalization, namely by ta'awun (cooperative) risk-sharing and a clear separation between participants and operators (Alamasi, 2010). According to world data, takaful or Sharia insurance growth reached 5 billion US dollars in 2019 (Statistica.com 2021). From this, it can be assessed that the growth potential of Sharia insurance is very high. But the growth potential of Sharia insurance assets is inseparable from the internal and external conditions of the company. 
Of the policies, the growth of Sharia insurance assets is heavily influenced by its investment policies (Sastrodiharjo \& Sutama, 2016). The investment cycle in Sharia insurance itself is also based on the amount of contribution. It takes into account the operating costs that must be covered by the investment results made. Meanwhile, investment results can also be influenced by external factors of insurance companies such as macroeconomics. But of these internal policies, some of them are very closely related to investment. External economic conditions exist that directly and indirectly have an impact on the growth of Islamic insurance assets. So it is necessary to see what factors affect the growth rate of sharia insurance assets so that Islamic insurance assets can continue to grow in the future.

In reality and from the market side, there needs to be an in-depth analysis of the overall factors that can be used as knowledge and insight into reality and trends to assess and decide sharia insurance operationalization policies. From here, you want to know, do internal factors such as investments, contributions, and operating costs affect the growth of Islamic insurance assets? And do macroeconomic factors such as GDP and inflation also affect the development of Islamic insurance assets? This study uses sharia insurance data in Indonesia in the OJK report for the period 2016-2020 to determine the factors that affect the growth of Sharia insurance assets in Indonesia.

\section{THEORICAL BASIS}

\section{Growth of Sharia Insurance Assets in Indonesia}

Sharia insurance in Indonesia is growing very rapidly. The competition in Sharia insurance is increasingly competitive. Many new Sharia insurance and reinsurance have sprung up to spin-off (Rusydiana \& Nugroho, 2017). The separation of sharia business units on Sharia insurance boosts the performance of its industry. Insyariah insurance products that continue to innovate quickly, where the product develops and adjusts to the needs of the market, as well as the quality of products with agreements that meet the provisions of the National Sharia Council fatwa, can add to the vigorous growth of Islamic insurance assets (Komite Nasional Ekonomi dan Keuangan Syariah, 2020).

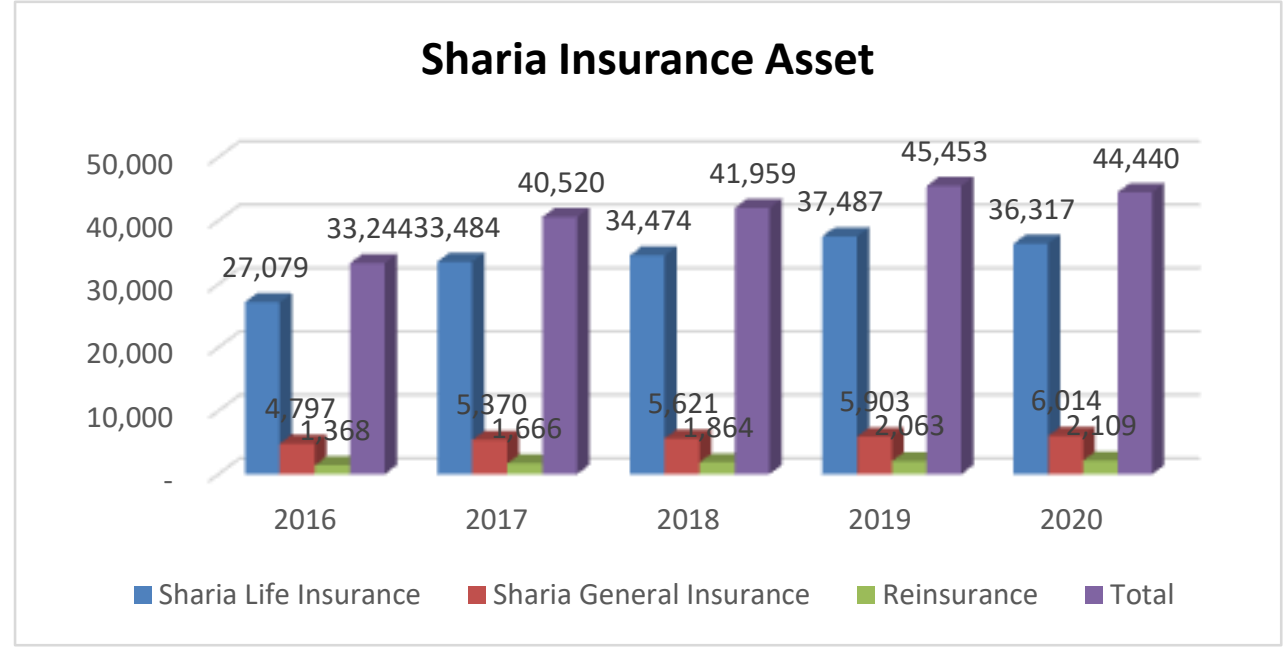

Figure 1

The Development of Amount of Sharia Insurance in Indonesia Source: OJK Data 
From the graph, it can be known that the growth of assets in Islamic life insurance is more dominant compared to other insurance industries. Because more and more people are aware of the importance of life insurance and the products, present always adjust the market's needs. In 2019 the total assets of Sharia insurance reached Rp 45.45 billion, with total Sharia life insurance reaching Rp 37.48 billion, general insurance amounting to $\mathrm{Rp} 5.9$ billion, and reinsurance amounting to Rp 2.06 billion. But in 2020 , there was a decrease in total assets of Rp 1,013 billion from $\mathrm{Rp} 45.45$ in 2019 to $\mathrm{Rp}$ 44.44 billion. This decrease is due to economic shocks that occurred in Indonesia starting in early 2020 due to the covid-19 pandemic that impacted all sectors of the economy (Laporan Triwulan OJK, 2020). However, from the data can be seen the decline in assets that occurred is not so significant.

Table 1. Number of Sharia Insurance 2018-2019

\begin{tabular}{clcc}
\hline No. & Company & 2018 & 2019 \\
\hline $\mathbf{1}$ & Life Insurance Company & & \\
& Full Fledged & 7 & 7 \\
& Sharia Business Unit & 23 & 23 \\
$\mathbf{2}$ & General Insurance Company with Sharia Principles & & \\
& Full Fledged & 5 & 5 \\
& Sharia Business Unit & 24 & 24 \\
$\mathbf{3}$ & Reinsurance Company & 1 & \\
& Full Fledged & 2 & 2 \\
& Sharia Business Unit & $\mathbf{6 2}$ & $\mathbf{6 2}$ \\
\hline & Total & &
\end{tabular}

Source: OJK Data

From the OJK report above that in 2019, the number of insurance and reinsurance companies was 62. This number is still the same as the number of insurance and reinsurance companies in 2018. Since the beginning of the emergence of the sharia insurance industry continues to increase, sharia insurance that continues to grow to reach 62 sectors in 2019 can see that the potential increase and development of Sharia insurance can continue to increase. The existence of government regulations related to minimum capital insurance and the discourse of Sharia insurance companies will spinoff based on insurance laws. It can be estimated that the Sharia insurance industry will continue to grow (Karim, 2017).

\section{Sharia Insurance Trends}

In the World Takaful Report, the Sharia insurance sector is globally centered in GCC member countries and Southeast Asia (Middle East Global Advisors, 2016). From the data published by (Ernst \& Young Global Limited, 2014), Malaysia became the first country to have a gross contribution rating of Sharia insurance in Southeast Asia, which is $71.28 \%$, then in the second country Indonesia is $22.72 \%$, then other countries. In Southeast Asian countries, the gross contribution of Sharia insurance occupies the second largest after Saudi Arabia (Sari, 2016). This is pretty reasonable because both countries have Muslim-majority populations, and Malaysia is a country that actively develops Sharia insurance. In addition, if observed, the potential of the sharia insurance 
industry will continue to increase in the future. Based on Global Takaful Insight data in 2014 , there is a growth in the global Islamic insurance sector of $14 \%$ annually. The insurance industry serves as a financial intermediator connected to the broader economic sector (Ernst \& Young Global Limited, 2014).

But from 2019 to 2020 in Indonesia itself in the Islamic insurance sector, there was a decrease in growth as of December 2019. The total sharia insurance assets in 2019 grew 8.44\% from the usual double digits. This growth projection is considered to be the same in 2020 (Republika 2020). According to OJK, the slowdown in the growth of the Islamic insurance industry is due to external factors of the company. If economic conditions decline, then the insurance industry is affected.

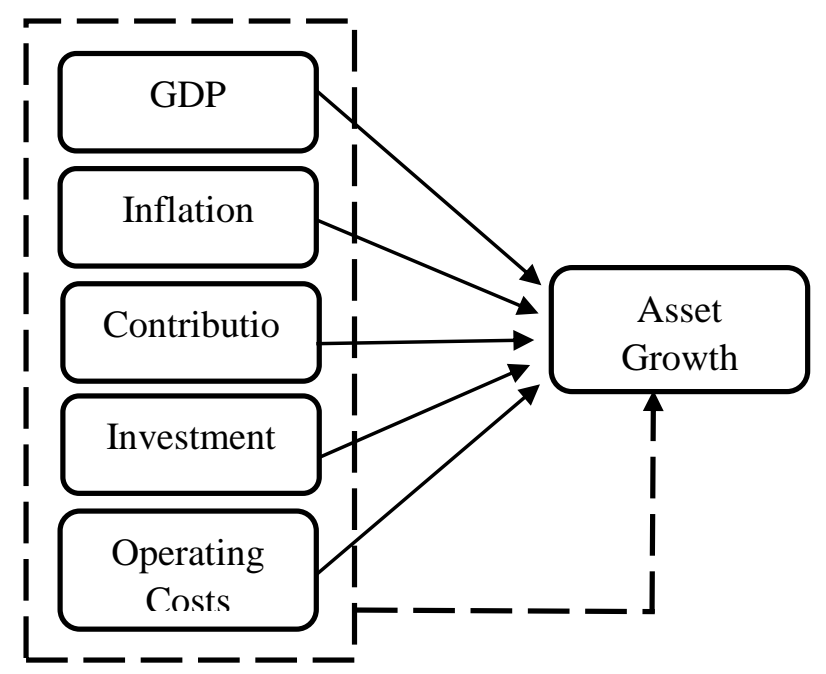

Figure 2.

Research Model of Growth Asset in Sharia Insurance

\section{LITERATUR REVIEW OF SHARIA INSURANCE}

Some research on Sharia insurance both in Indonesia and in some countries discusses the efficiency of Sharia insurance and conventional insurance, while others discuss performance. Still, not much has been concerned about factors that affect the growth of its assets. Here is a description of some previous research on Sharia insurance.

(Rusydiana \& Nugroho, 2017). The purpose of this research is to measure the efficiency level of the life insurance industry in Indonesia. The method used is Data Envelopment Analysis (DEA). There are eight sharia insurance industries that are the object of research: Prudential, BNI Life, PaninDai-IchiLife, Asuransi Jiwasraya, and Adisaranan Wanaartha Life Insurance, Takaful Takaful Insurance, Amanahjiwa Giri Sharia Insurance, and Al-Amin Sharia Life Insurance. The variables in the study were three input variables of Commission Cost (X1), Operating Costs (X2), Total Equity (X3), and two variable output (Premium) (Y1) and Investment Income (Y2). This study results show that as many as 15 DMU are very efficient (100\%) and inefficient as much as 24 DMU. From this, it can be known when compared to other life insurance, 
Prudential insurance is a life insurance company that can maintain the level of efficiency from 2013 to 2016 . From these results, it is also known that the main factor in the inefficiency of the life insurance industry in Indonesia from 2012 to 2016 is output.

Further research was conducted by (Lilavira \& Zulaikha, 2020), which aims to find out the effect of operational costs, growth in investment returns, contributions, and profitability on the growth of Islamic insurance company assets. The study used data from 2013-2017 on Islamic insurance financial statements with 21 samples and used multiple linear regression analysis techniques. This study shows that three variables have a significant positive effect on asset growth: growth in return on investment, contribution, and profitability. In contrast, operating costs do not have a significant influence.

(Al-Amri, 2015) examined the performance of takaful companies in GCC countries with the DEA analysis approach method. The results obtained from observations are known that the Islamic insurance industry in GCC is very technical and efficient. The result is that Sharia insurance is also cost-effective and has an excellent opportunity to make rapid growth and improvement. The UAE and Qatar dominate the highest technical efficiency, while Saudi Arabia and the UAE are the most costeffective GCC countries.

In addition, in research conducted by (Hidayat \& Firmansyah, 2017) on Good Corporate Governance in Sharia insurance companies in Indonesia. The data used is 15 insurance companies in Indonesia with the period 2011-2015. It was obtained that the board of directors did not affect the financial performance of Islamic insurance. And board variables, managerial ownership, institutional ownership, and leverage positively influence the financial performance of Islamic insurance in Indonesia. Meanwhile, the company's size weakens the relationship between the number of directors and leverage with financial performance. It does not moderate the relationship between the number of board of commissioners, managerial ownership, and institutional ownership of the financial performance of Islamic insurance in Indonesia.

The research was conducted by (Istiqomah \& Gati, 2020) to find out the effect of operational costs, investment results, claims, and tabarru funds' on sharia general insurance contributions in Indonesia for the period 2015-2018. The data used is secondary data from the publication of financial statements with 44 observational data. The study used regression analysis with fixed effect model (FEM) panel data. It is known that, partially, variable operating costs, claims, and tabarru funds' positively affect participants' contributions. This means that these variables will affect the determination of participants' dues. While the variable of investment results has no does not affect the determination of participants' dues because funds can be used to increase assets

And the last research conducted by (Faoziyyah \& Laila, 2020) aims to test the company's internal and macroeconomic factors against the profitability of Islamic insurance companies in Indonesia (Return On Asset). This study uses sharia insurance 
data in Indonesia for the period 2015-2018 with the fixed-effect model estimation method with the Weighted Least Square (WLS) method obtained the result that the company's size, contribution growth, retakaful, leverage, return on investment, GDP, and inflation jointly affect the profitability of Islamic insurance companies in Indonesia. While partially, the growth of contributions and investment returns has a positive and significant influence on the profitability of Islamic insurance companies in Indonesia. The size of the company and GDP were found to have a positive and insignificant effect on the profitability of Sharia insurance in Indonesia. While leverage, retakaful, and inflation have a negative and not significant influence on the profitability of Islamic insurance companies in Indonesia.

\section{METHOD}

This study uses a quantitative approach with secondary data obtained from the Sharia Financial Statement Statistics published by OJK and Bank Indonesia Statistics from 2016 - 2020. This report contains various sources of information such as investments, operating expenses, claims, contributions, GDP, etc.

This research aims to find out the influence of internal variables and external variables on the growth of Islamic insurance assets in Indonesia. In this study, there are two variables, namely dependent variables, and independent variables. Dependent variables are the growth of sharia insurance assets in Indonesia (PERASSET), and independent variables, namely GDP (GDP), inflation (INF), contribution (KONB), investment (INVEST), and operating costs (BOPERATE). The table below describes the definition of a variable operation as follows:

Table 2. Variables Description

\begin{tabular}{lll}
\hline \multicolumn{1}{c}{ Variable } & \multicolumn{1}{c}{ Description } & \multicolumn{1}{c}{ Indikator } \\
\hline PERASSET & Asset Growth & $\begin{array}{l}\text { Increase or decrease in total } \\
\text { assets in the company. }\end{array}$ \\
INF & Gross Domestic Product & $\begin{array}{l}\text { The value of goods and services that can be } \\
\text { produced in a country } \\
\text { for a certain period of time } \\
\text { General increase in prices from one period to } \\
\text { another }\end{array}$ \\
KONB & Contribution & $\begin{array}{l}\text { Funds from } \\
\text { participants are savings funds } \\
\text { and tabarru' funds paid according to the } \\
\text { agreement } \\
\text { Total funds invested by the company } \\
\text { INVEST }\end{array}$ \\
BOPERATE & Operating Costs & Total costs incurred by the company \\
\hline
\end{tabular}

Source: Processed from various sources

The purposive sampling method with samples is Sharia General Insurance, Sharia Life Insurance, and Sharia Reinsurance in Indonesia. With multiple linear regression 
analysis methods to estimate the value of dependent variables based on independent variables and determine the effect of independent variables on dependent variables (Istiqomah \& Gati, 2020).

Hypothesis testing is done simultaneously and partially. (1) Simultaneous Significance Test ( $F$ test) to determine the effect of independent variables on dependent variables together (Kuncoro, 2013). (2) Partial Significance Test (t-test) to determine the effect of independent variables on dependent variables if other independent variables are considered constant (Ghozali, 2018). And to test between the growth of Islamic insurance assets and the variables that affect them, the econometric model built is as follows:

PERASSET $=a+b_{1}$ GDP $+b_{2}$ INF $+b_{3}$ KONB $+b_{4}$ INVEST $+b_{5}$ BOPERATE + e....(1)

\section{RESULT AND DISCUSSION}

From the results of multiple linear tests on Sharia insurance data in Indonesia in 2016-2020 consisting of sharia general insurance data, Sharia life insurance, and Sharia reinsurance, the following results are obtained:

Table 3. Research Results

\begin{tabular}{lllll}
\hline Variable & Coefficient & Std. Error & t-Statistic & Prob. \\
\hline C & 4.556 .512 & 2.057 .907 & 2.214 .149 & 0.0000 \\
GDP & -2.162 .042 & 0.578505 & -3.737 .294 & 0.0005 \\
INF & -2.378 .545 & 0.588894 & -4.039 .004 & 0.0002 \\
KONB & 2.264 .243 & 0.609275 & 3.716 .289 & 0.0005 \\
INVEST & -0.003854 & 0.001385 & -2.782 .333 & 0.0074 \\
BOPERATE & 0.000761 & 0.001636 & 0.465357 & 4,46875 \\
R-squared & 0.494107 & F-statistic & & 1.054 .837 \\
Adjusted R-squared & 0.447265 & Prob(F-statistic) & 0.000000 \\
\hline Source: Eviews Processed
\end{tabular}

Source: Eviews Processed

The multiple linear regression equations in this study are:

$$
\begin{aligned}
\text { PERASSET }= & 45,5651-2,1620 \mathrm{GDP}-2,3785 \mathrm{INF}+2,2642 \mathrm{KONB}- \\
& 0,0038 \mathrm{INVEST}+0,0007 \mathrm{BOPERATE}+\mathrm{e} \ldots .(2)
\end{aligned}
$$

The above data results show that together or simultaneously, independent variable (X) affects the dependent variable (Y) of the Prob value (F-statistic) $<0.05$, which means H1 is accepted or in other words that variables in GDP, inflation, contribution, investment, and operating costs affect asset growth.

And based on the above results, it is known that independent variables of GDP, Inflation, Contribution, and Investment have a partial effect on the dependent variables Of asset growth with a probability value smaller than the critical value used, which is $5 \%$ or 0.05 . At the same time, independent variable operating costs do not affect dependent variables Asset growth with a probability value greater than a critical value of 0.05 or $5 \%$. 
The results of the hypothesis test can be concluded as follows:

1) GDP shows the value of coefficient -2.1620 with a probability value of 0.0005 , this indicates the relationship and influence of GDP on asset growth, where every increase in GDP every 1 unit then the asset growth rate decreased by 2.16 in the period 2016-2020.

2) Inflation (INF) has a coefficient value of -2.3785 with a probability value of $0.0002<0.05$, which means that inflation affects asset growth. In 2016-2020, with every increase in inflation of 1 unit then the asset growth rate decreases by 2.37 .

3) Contribution (KONB) has a coefficient value of 2.2642 and a probability value of $0.0005<0.05$, which means that the contribution affects asset growth, we're in the research period 2016-2020, each increase in the contribution by 1 unit then the asset growth rate increases by 2.26 .

4) Investment (INVEST) has a coefficient value of - 0.0038 and a probability value of $0.0075<0.05$, indicating that investment has an effect on asset growth, wherein the research period 2016-2020, every increase in investment by 1 unit will reduce the asset growth rate by 0.0038 .

5) Operating expenses (BOPERATE) show a coefficient value of 0.0007 and a probability value of $0.64>0.05$, which means that operating expenses do not affect asset growth.

\section{Simultaneous Effect of GDP, Inflation, Contribution, Investment, Operating Costs on Asset Growth}

The results of the above data are known that together independent variables, namely GDP, Inflation, Contribution, Investment, Operating Costs affect the dependent variables, namely Asset Growth. This is evidenced by the F test with a signification value smaller than $0.05(0.00<0.05)$. Several variables in this study can be distinguished into external factors, namely GDP and Inflation, and internal factors, namely contribution, investment, operational costs. GDP and inflation are external factors that are macroeconomic variables. This macroeconomic variable is an indicator of a country's development and continuous price increases. This can affect the ability of the community to save and invest in Sharia insurance. Meanwhile, internal factors affect in terms of the ability to manage funds in Islamic insurance companies.

\section{The Effect of GDP on Asset Growth}

Based on this study's results, GDP has a significant negative effect on the growth of Islamic insurance assets in Indonesia. This study is different from research conducted by (Faoziyyah \& Laila, 2020), where GDP does not affect ROA.

GDP is a macroeconomic factor that can be an indicator of a country's economic growth. Rising GDP can be attributed to increased employment, investment growth, rising wages. But in this study, GDP effects reducing the growth of Islamic insurance assets. Whoever is possible because the consumption of Sharia insurance products in this research period is less sensitive to economic growth because Sharia insurance products have reached saturation point (Ward \& Zurbruegg, 2000). This phenomenon is because people prefer to manage their risk with other financial portfolios that they have. 
In addition, in the final year of this study, in 2020, there was a shock of a health crisis due to the covid-19 pandemic that also had an impact on economic conditions in Indonesia where people prefer to withhold their income to meet daily consumption needs because funds for saving and community investment are limited.

\section{Effect of Inflation on Asset Growth}

In this study, inflation has a significant negative effect on asset growth. High-rate inflation will affect the decline in insurance demand because an increase in inflation leads to a devaluation of future benefits on insurance purchases (Ward \& Zurbruegg, 2000). The decrease in insurance demand will undoubtedly affect the reduction in the growth rate of insurance assets.

\section{Effect of Contribution to Asset Growth}

The contribution showed a significant positive effect on the growth of Sharia insurance assets in Indonesia. These results are by research conducted by (Faoziyyah \& Laila, 2020) and (Lilavira \& Zulaikha, 2020).

Contribution is one of the sources of funding needed by Sharia insurance, in addition, the contribution is also a source of income for Sharia insurance. The more contribution the company gets, the greater the growth of its assets. This means that the more significant the contribution of Islamic insurance investment funds, if the investment funds of large companies, then the profit obtained is greater. If the profit is large, then asset growth is increasing as well.

\section{Effect of Investment on Asset Growth}

Partially, investment has a significant positive effect on asset growth. When investment increases, asset growth will also increase. This is supported by research conducted by (Faoziyyah \& Laila, 2020) and (Lilavira \& Zulaikha, 2020).

In fatwa No.21/DSNMUI/X/2001, it is explained that sharia insurance companies, as holders of responsibility for the funds of participants who have been collected, must make investments. The investment fund must be managed based on sharia principles to get investment returns. Akad commonly used in Sharia insurance is mudharabah, musyarakah, salam, istishna. Investment returns are divided on the principle of revenue sharing. Investment profits will be driven and divided into two between the insurance company and the customer.

\section{Effect of Operating Costs on Asset Growth}

Operating expenses are costs incurred for the company's operational activities so that its business can continue to run. But the results of this study showed that operating costs had no significant effect on the growth of Islamic insurance assets.

This can show that the funding of Islamic insurance companies comes from internal such as operating costs and externals such as debt, bonds, and others. So that operating costs do not always impact asset growth (Lilavira \& Zulaikha, 2020). 


\section{CONCLUSION}

From this research, it can be known that from several factors that affect the growth of assets of sharia insurance companies, four factors affect asset growth, namely GDP, inflation, contribution, investment. And 1 factor does not affect asset growth, namely operating costs. But simultaneously, these factors affect the growth of assets.

From this research, it was also found that Sharia insurance's ability to manage and make investment policies and contributions has an impact on the growth of Sharia insurance assets. In addition, the ability to see the potential for economic growth will also affect the growth cycle of Islamic insurance assets.

Macroeconomic factors influence the growth of Islamic insurance assets, which means that the thoroughness of reading the socio-economic situation and opportunities significantly impacts the development of Islamic insurance assets. From this, it is expected that sharia insurance actors and activists are more innovating to make Sharia insurance products that follow the needs of the community so that the community again has confidence and is passionate about making Sharia insurance part of its financial portfolio, especially in difficult times such as in the conditions of the covid-19 pandemic where many people will prefer to use their funds for their consumption needs rather than invest in Sharia insurance. In addition, the manager of Sharia insurance companies to focus on investment and contributions because the more significant the allocation of fund management in both internal factors can be the way sharia insurance assets will continue to grow and run smoothly.

\section{REFERENCES}

Al-Amri, K. (2015). Takaful insurance efficiency in the GCC countries. Humanomics, 31(3), 344-353. https://doi.org/10.1108/H-05-2014-0039

Alamasi, A. (2010). Surveying developments in Takaful industry: prospects and challenges. International Association for Islamic Economics Review of Islamic Economics, 13(2), 195-210.

Ernst \& Young Global Limited. (2014). Global Takaful Insights 2014. EYGM Limited, 16. http://www.ey.com/Publication/vwLUAssets/EY_Global_Takaful_Insights_2014/\$ FILE/EY-global-takaful-insights-2014.pdf

Faoziyyah, A. A., \& Laila, N. (2020). Faktor Internal Dan Faktor Makroekonomi Yang Mempengaruhi Profitabilitas Asuransi Syariah Di Indonesia Periode 2016-2018. Jurnal Ekonomi Syariah Teori Dan Terapan, 7(6), 1146. https://doi.org/10.20473/vol7iss20206pp1146-1163

Ghozali, I. (2018). Aplikasi Analisis Multivariate dengan Program IBM SPSS. Badan Penerbit Universitas Diponegoro.

Hidayat, I. P., \& Firmansyah, I. (2017). Determinants of Financial Performance in The Indonesian Islamic Insurance Industry. Etikonomi, 16(1), 1-12. https://doi.org/10.15408/etk.v16i1.4648

Istiqomah, A., \& Gati, V. (2020). Risk Effect on Contribution of Participants in Sharia Insurance Indonesia. Jurnal Ekonomi Dan Bisnis Islam (Journal of Islamic Economics and Business), 6(1), 1. https://doi.org/10.20473/jebis.v6i1.18254

Karim, A. (2017). Islamic insurance 2017.

Khan Atiquzzafa, \& Uzma Noree. (2014). Efficiency Measure of Insurance vs Takaful 
Firms Using DEA Case Pakistan. Islamic Economic Studies, 22(1), 139-158.

Komite Nasional Ekonomi dan Keuangan Syariah. (2020). Asuransi Syariah Capai Pertumbuhan Produktif 2020. Insight: Buletin Ekonomi Syariah, 9.

Kuncoro. (2013). Metode Riset Untuk Bisnis dan Managemen. PT. Erlangga.

Laporan Triwulan OJK. (2020). I-2020.

Lilavira, A., \& Zulaikha, S. (2020). Analisis Faktor-Faktor Yang Mempengaruhi Pertumbuhan Aset Pada Perusahaan Asuransi Syariah Periode 2013 - 2017. Jurnal Ekonomi Syariah Teori Dan Terapan, 7(2), 305. https://doi.org/10.20473/vol7iss20202pp305-318

Middle East Global Advisors. (2016). World Takaful Report 2016. 11th Annual World Takaful Conference, 1-50.

No.21/DSNMUI/X/2001. (n.d.). Fatwa DSN-MUI No.21/DSN-MUI/X/2001 tentang Pedoman Umum Asuransi Syariah. 1-7.

Rusydiana, A. S., \& Nugroho, T. (2017). Measuring Efficiency of Life Insurance Instution in Indonesia: Data Envelopment Analysis Approach. Global Review of Islamic Economics and Business, 5(1), 012-024.

Sari, K. (2016). Perkembangan Asuransi Kesehatan Swasta di Indonesia Tahun 20122016. Jurnal Ekonomi Kesehatan Indonesia, 2(2), 48-58.

Ward, D., \& Zurbruegg, R. (2000). Economic Growth ? Does Insurance Evidence From. The Journal of Risk and Insurance, Vol. 67(ARIA, American Risk and Insurance Association), pp.489-506.

Wibi Pangestu P, " Kinerja Kuartal I/2021 Industri Asuransi Umum Tokcer, Ini Pemicunya", https://finansial.bisnis.com/read/20210502/215/1389293/kinerjakuartal-i2021-industri-asuransi-umum-tokcer-ini-pemicunya.

Ama Puri, dkk, " Value of Takaful Asset", https://www.statista.com/statistics/1090916/worldwide-value-of-takaful-assets-bycountry/.

Lida Puspaningtyas, “ OJK: Perlambatan Asuransi Syariah Karena Faktor Eksternal”, https://www.republika.co.id/berita/q6bii1370/ojk-perlambatan-asuransi-syariahkarena-faktor-eksternal.

Diah Nugraheni, "Kondisi Ekonomi, Politik, dan Permintaan Terhadap Asuransi", https://www.indonesiare.co.id/en/article/kondisi-ekonomi-politik-dan-permintaanterhadap-asuransi. 